\title{
National Identity and the Challenge of the Church in Latvia Today.
}

\author{
By Guntis Dislers
}

1.The present situation in Latvia's religious life can be described as multi-dimensional. We can see the interrelation of at least three different perspectives: a pagan heritage, coming from IndoEuropean (Baltic) sources, Christianity (represented in Catholic, Orthodox, Lutheran and smaller Protestant denominations), and Neo-paganism (including MT, New Age, Hare Krishna, and similar movements). Of course each dimension or perspective represents different social groups, but it must be said at the same time that all three of these dimensions are represented in the same man, or the same group or circle of people. Because of $\mathbf{5 0}$ years of official atheism and materialism, people have partially lost their religious vision; they are illiterate as far as these questions are concerned and therefore tend to mix different conceptions of faith.

2. The Indo-European background in Latvian culture and religious life is very important and powerful. Latvians together with Lithuanians (and formerly Prussians) represent the Baltic branch of the Indo-European »family tree «, and they speak the oldest language in the whole family. This means that in the Latvian language, scientists such as linguists, mythologists, folklorists, and ethnographers can find a lot of unique material for their studies. If compared with the Vedas for example, Latvian and Lithuanian folk songs (called »dainas $\%$, plural) contain old words, roots, phrases and concepts which help to reconstruct the oldest strata of the understanding of the world as it must have appeared to our ancestors. The Latvian and Lithuanian languages and cultural heritage are studied all over the world - in the USA, in Europe, etc. - because of their unique character.

Apart from its value from a scientific point of view, this heritage has been used in different ways through the history of the Latvian nation. What is now Latvia was conquered by German crusaders in the 12th and 13th centuries, and after that the 
people was under German occupation for ab. 700 years (simply speaking about a German occupation is to simplify things; we also talk about "Swedish" and "Polish « times). Latvians were enslaved, they spoke their language at home and followed their own traditions, but education and higher positions in their society were closed to them. We cannot speak about Latvia as a nation until the 18th or 19th century when the first Latvian schools, books and magazines appeared. Before that, folklore was their school, their books and newspapers, so to speak, and last, but not least, the foundation of their future culture. Because they had their own language, their folk-songs, their traditions, their own religion, Latvians survived. Children were educated in the main-stream of tradition, following the patterns set by their ancestors in ancient times. Latvians were forced to live a »double life «, an official life under occupation, and a life of their own at home, according to tradition.

3. The Indo-European heritage was not understood as the basis and argument for national self-pride and popular awakening until after the German occupation. The Germans always claimed that Latvians were stupid, illiterate and ignorant, until the Germans arrived. In the 18th century Latvians themselves began to claim openly that they represented a very old culture, and that they were not so »thin« as the Germans drew them. Many publications appeared in newspapers and year-books, poems were composed etc. (for example about the Latvian language being spoken in Northern India, about an Indo-European 'Urheimat' somewhere in India, about Latvians as true Indo-Europeans, etc.). Of course, these publications were naive, but they served their purpose: to prove the Latvians' importance, their rich history, their connection with other nations, and their contact with the important cultures of the world.

4. Alongside with the beginnings of a political struggle against German occupation in the 18th and 19th centuries, a new tendency in the use of the Indo-European heritage began to appear at the dawn of the 20th century. The heritage began to be seen as a bridge to the Eastern world of thought, especially the Vedas, Vivekananda, Tagore and others. The world of the Vedas 
was understood as the long-term perspective of Latvian folk tradition in a religious sense. Vedanta was looked upon as the Latvians' natural religion, as a key to their self-understanding. What was un-developed in their own philosophy, was revealed in Vedanta.

Latvian literary classics use many Indian and Vedic ideas and concepts in the novels and poems from the beginning of the 20th century. It is a mystic tradition in a way. In the so-called Soviet Latvian literature some poets also use these motifs to express mystic ideas and to reveal the sacred depths of Latvian folklore against the superficial Soviet class-struggle ideology. At that time (under the Soviet Communist regime), any interest in this direction was considered intellectual opposition to official ideology, and precisely because it was forbidden to read or discuss spiritual matters of any kind, it seemed to many people to be highly scholarly, interesting, and intriguing. In the late seventies a film was made by Riga Cinema Studio about the sacred meaning of Latvian ornamentation (compared with Hindu, Tantra, and Zen). It showed motifs such as pre-natal life, life after death, reincarnation, the eternal soul (Atman), seeking one's roots, darkness and light, enlightenment etc., widely used in much popular poetry and music (though, of course, it was done within the framework of »allowed « art).

5. Even today when Christianity has come back into the normal life of our society, many so-called intellectuals think that the spiritual side of life is more "serious « if looked upon from the point of view of our present life, because it is bound up with its national basis and accepted world-wide as tradition, to be investigated scientifically. There is no need for faith or trust in God, because God is, and $\mathrm{He}$ works as fate, as the ruler of matter even in subtle forms (as aura). They think that Christianity is necessary for old and weak people who are unhappy or dissatisfied with their lives, who have nothing to lose, who are ignorant and stupid. Perhaps the same problem is to be found in Denmark, too?

6. After the fall of the »Iron Curtain«, which had separated Latvia from the West, a host of spiritual influences from abroad 
have poured in over the last few years. There was a kind of spiritual "vacuum « in Latvia (as everywhere in the former USSR), since people had not been educated to have any genuine understanding of our life on earth. They welcome everything in their life because they want the best. Perhaps we can compare this situation with that of the Romans when they worshipped all gods, wanting guarantees for their security, welfare, etc. "What good will TM do us? « people ask - and take it. "What good will paganism do us? « they ask - and take it. »What good will Christianity do us?« they ask - and take it. People are not genuine believers, but simply take religion as a thing to buy, like goods in a shop. And like shoppers, they will take what is most glittering, regardless of quality. Christianity may not, taking this simile a step further, always be glittering, though it is certainly the best quality, but people want cheap things sold in the supermarket. This also bears on the question of mission work here: Christians have no money to publish glittering editions, whereas Bahai and Hare Krishna have beautiful, picturesque books. And people prefer to buy the latter.

7. Extrasensory healing methods, using »spiritual« power, were and still are very popular with people in Latvia. There are two reasons for this: 1) poor medical treatment, low-quality doctors, often unable to make the correct diagnosis, and 2) ignorance of the spiritual side of life; people trust »magicians «, »sorcerers « and whealers $\%$, because they can make a diagnosis without analysis, just by having a look at the patient. But we know that these energies work, that they have an effect, that they are somehow very powerful, but we do not know the exact character of this effect. We have a special term for this influence: "psycho-fascism*, because »healers influence not only the body, but also the soul, leading it to depressions and desolation. These »healers $*$ were very popular, especially in the first years of the period of awakening (1988-1990) when the USSR Empire began to feel the danger of a catastrophe very seriously. Healers did not only work in the USSR, but also in other former Communist states, such as Bulgaria. They even used TV and radio and influenced millions and millions of people. According to statistics, the number of deaths among an audience subjected to the 
treatment of healers is ab. 3-5 times higher than normal. The use of the mass media for this purpose may have had ideological overtones, since USSR television programmes were always under KGB control, and there were no private programmes.

8. Astrology is not only part of the New Age Movement, but daily fare for ordinary people. There is probably no newspaper in Latvia without an astrological forecast for the coming week. People are looking for stability, for their roots, and for the forces that affect them. This is important for them, because we have no official ideology any more to advise us about what to do, where to go, etc. As it is, people do not know what to do and where to go; they don't even know what to pray for or how to pray for that matter. Astrology becomes their fate and destiny, a »fortress where they seek protection and consultation.

9. As it has been said above, Christianity was introduced in Latvia as early as the 12th and 13th centuries when Livonia (what is now Estonia and Latvia) was conquered by crusaders from the West. The people was enslaved, and Germans ruled here for ab. 700 years, until the proclamation of Latvias's independence in 1918. We know from history and old chronicles that at least until the 18th century Christian priests and pastors were mainly Germans (The Latvians used to have this saying "No one understands what this German cat is speaking about $\alpha$, referring to the Sunday service). Christianity was the »official« religion, though only in a purely formal sense. People followed their old pagan ideas and habits, worshipping old gods (polytheism). To Latvians, Christianity was associated mainly with conquerors, oppressors, and foreigners in general. Later, in the beginning of the 20th century, a national religious movement, the "God-holders* (dievturi) was founded by a Latvian, E. Brastins, based on folk literature and the Indo-European background, and supposed to promote national self-understanding, as against the $» J e w i s h-$ German Occupant religion $\kappa$. The main idea was this: Christianity is, in essence, hypocritical, cynical, cruel, and foreign to Latvians because they have their own national religion. So there!

10. In 1940, when the Baltic states were occupied by the USSR and incorporated in Stalin's Empire for 50 years, the official 
ideology became Marxism-Leninism, which proclaimed atheism and perse-cuted not only Christians but anybody seeking spirituality. They were deported, tortured in KGB prisons, or shot dead as »bourgeois spies, anti-Communists, enemies of the working-class «, etc. The Church was separated from the state, but not vice versa (this being a de facto truth, though, of course, not an official one). All cultural and ideological acitivity was pervaded with Communist ideas and Marxist propaganda, following CPSU directives. There was no such thing as a serious dialogue between Christians and society at that time. Of course, the Church existed, regardless of persecutions, but pastors were under control, Sunday schools were forbidden, the Faculty of Theology at the University of Latvia was closed down, the clergy was ridiculed, etc. All foreign contacts were broken off, except in some cases when it was necessary to show foreigners that church life was normal and not subject to KGB control. It looked nice enough on the outside, but in reality we know of many sad stories.

11. The church life was renewed only because of the process of awakening in the late $1980 \mathrm{~s}$. We can't say »because of perestroika since, as we know now, perestroika was not intended as a liquidation of the CPSU and the USSR, but only as a wre-arrangement $\kappa$ in certain areas. We are proud that young Lutheran pastors were the first to begin speaking about persecutions under the Communist regime; the movement »Renewal and Rebirth * together with the human rights defence group, "Helsinki $86 \%$, were a kind of pioneers in this process in 1986-87. They asked for religious freedom, for the right to attend church without a bad conscience and without persecution, for the right to elect bishops without injunctions from above, and for the right to publish Christian literarure. Some of them were severely persecuted and even had to leave Latvia (they now live in Germany, Canada, and Australia), but the situation changed in 1989, when, for the first time after World War II, a new archbishop was elected. Karlis Gailitis began his Christian life some 20 years ago, and he went through some hard times in his lifetime. He began studies in the sphere of agriculture, worked for some time in that field, but very soon discovered that his life could be 
meaningless if he continued. So he began to serve in different congregations, and had to bear a great deal of suffering because of his courage, until he was elected by the Synod in 1989. Sadly, he died in November 1992 in a car accident. His work had many dimensions: to take care of congregations (in 1940 there were 300 Lutheran congregations in Latvia, in 1960 there were only 100 left, and there are now 270), to plan the education of clergymen, to keep contact with the churches of Latvian refugees abroad etc. The Lutheran Church was poor, and the pastors were few and old. A number of possibilities opened up, but the Church was in great need of money. The Archbishop had to represent our Church abroad and establish Ecumenical contacts. Since the Iron Curtain was destroyed so rapidly, there were not enough people who were prepared and able to do the work required, who could speak foreign languages, and who could lead people in prayer. Gailitis worked hard, and when the duties became too hard and too much for him to take them on alone, he asked for help, protection, friendship and support.

12. There are two generations of pastors - old and young, very few in between. The old pastors were educated before World War II at The Faculty of Theology at the University of Latvia, and the young ones are studying now, while at the same time serving 2-5 congregations who are waiting for them to conduct a service at least once a month. There are 110 pastors in our Church, and one third of them are still students. The young pastors are too young for normal church work because of their lack of experience, and the old ones are too tired and, sad to say, too conservative of outlook in the present situation, since their most productive work was carried out under the Communist regime. One of the most immediate needs, therefore, is to involve lay people in the life of the congregation.

13. As far as education is concerned, we had a Lutheran seminary, a two-year course, during the Communist regime. Naturally, the level of education was not high, but it was something! All the graduates from this seminary are working now, and also teaching at the re-established Faculty of Theology. The Faculty was re-opened in 1990. It now offers 4 courses, and there are 
130 students (50\% male, $50 \%$ female). The Faculty invites guests from abroad (both Latvians and non-Latvians) to teach different subjects, and students who have distinguished themselves go into practice here or abroad. The Faculty does not guarantee work for them, and a decision about ordination depends on the Church Consistory. Both ordained and non-ordained students are involved in parish work.

14. If we turn to the subject of Sunday school education, it should be said that 130 congregations have their own schools. They need teachers, of course, and over the last four years there have been special courses for them in Riga. These weekly courses, held from September to May, and teaching different subjects, are paid for by the Consistory and the Christian School.

The first Christian school was opened in Riga in 1990, and we are looking forward to having more in the future.

15. Diaconal work is still undeveloped.

16. As far as publishing activities are concerned, we have published some books for new beginners, but the very high prices of paper make publishing very difficult for us. We have a weekly newspaper, „Svétdienas Ríts « (Sunday Morning), which began publication again in 1989. It is mainly Lutheran, but is also open for Ecumenical contacts. (There is another newspaper, Solis (step), monthly, published by the Catholic Church.) As it was done also previously, we publish a socalled year-book every year (a calendar with articles, essays, etc.)

17. Latvian refugees live all over the world - in the USA, Canada, Sweden, Australia, Germany, the UK - and everywhere they have Lutheran congregations. There are also some Catholic congregations, though not quite so many. Because of political restrictions, close ties with Latvian congregations abroad used to be difficult, but starting from 1989 we aim at establishing one united Latvian Lutheran Church step by step. The General Synod will be held in the summer of 1992, when the new archbishop for the whole church will be elected (at present we have one bishop in Riga, and another for those in exile will be elected in March). This means that we shall have an agreement 
about the exchange of pastors and common practice in basic questions (ordination of women, pre-confirmation education, Faculty lecturing, finances, etc.)

18. As far as ecumenical contacts are concerned, Latvia has the following denominations: Lutherans (officially ab. 300,000, i.e. $1 / 3$ of the population), Catholics (1/5 of the population), Russian Orthodox, Baptists, both Latvian and Russian, Adventists, and some smaller denominations. We have no special interdenominational agreements, but in the basic questions of our society over the last few years we have acted together - for independence, for Christian values regardless of nationality, for love and peace and cooperation. There are no clergymen in Parliament at present, but we have a Christian Democrat Party which is quite active on TV and radio, and which is getting ready to participate in elections (in the summer of 1992). We have not given our support to anybody yet, so we still have some time to consider this question seriously. 